\title{
The Effect of Treated (Spray-Dried) Beef-Tallow Supplementation on Feed Digestion, Ruminal Fermentation and Fat Nutrition in Sheep
}

\author{
Tsutomu FUJIHARA, Satoshi MAEDA, Tohru MATSUI* \\ and Harumi NARUSE** \\ Faculty of Life and Environmental Science, Shimane \\ University, Matsue-shi 690
}

(Received July 17, 1995)

\begin{abstract}
Two experiments were carried out to examine the effect of the supplementation of treated beef tallow (BT) on feed digestion, and to investigate the possibility of using it to improve fat nutrition in fattening lambs. Apparent digestibilities of organic matter and other nutrients were not affected by supplementing BT to feed ( $1 \% / \mathrm{DM})$, although the digestibility of crude fiber tended to decrease when the dietary BT level was relatively high ( 2 to $4 \% / \mathrm{DM})$. The ruminal level of propionic acid tended to increase, and acetic acid level tended to decrease with BT supplement. Also, the ratio of acetic acid to propionic acid (A : P ratio) was lowered after feeding BT diet. The plasma level of glucose was higher $(P<0.05)$ after feeding $B T$ diet than that after feeding control diet. The plasma concentrations of triglyceride and cholesterol tended to increase $(\mathrm{P}<0.05)$ in feeding BT diet as compared with that in feeding control diet. From these results, a possibility was suggested that BT was useful to improve fat nutrition, when it was supplemented to the diet for sheep as an energy source after treatment (spray-dried).
\end{abstract}

Anim. Sci. Technol. (Jpn.) 67 (1) : 14-23, 1996

Key words : beef tallow, feed digestion, fat nutrition, fattening Sheep

It has been well established that fats (mainly vegetable fat) reduced the digestibility of crude fiber in ruminant rations ${ }^{1.17)}$, and addition of minerals to a ration containing fats counteracted depression of the digestibility caused by supplementation of fat for the purpose of raising dietary energy density ${ }^{3,8}$. It was reported that addition of animal fats to ruminant ra- tions, indicated a slight increase in daily gains of steers supplemented with animal fat to the ration $^{13,2)}$, and a little positive effect of supplemented tallow ester on improving feed efficiency in fattening beef cattle ${ }^{\left.{ }^{1},{ }^{*} 3\right)}$.

In recent years, it has been found that supplementation of fats (including animal fat) in the form of calcium soap of fatty acids can

\footnotetext{
* Present address : Faculty of Agriculture, Kyoto University, Sakyo-ku, Kyoto-shi 606

** Present address : Kyokutoh International Co. Ltd., Minato-ku, Tokyo 105

*1) Itakura F, Kondoh I, Takahashi A. Res. Bull. Aichi Agric. Res. Cent., 15 : 375-381. 1983. (in Japanese).

${ }^{* 2)}$ Okano K, Nakamura T, Moriwaki K, Okumura T. Sci. Repo. Shiga Pref. Jr. Colle., $27: 37-42.1985$. (in Japanese).

${ }^{* 3)}$ Okano K, Nakamura T, Suzuki Y, Okumura T, Hosoi Y. Sci. Repo. Shiga Pref. Jr. Colle., 29 : 7-12. 1985. (in Japanese).
} 
be used to provide calories to feed lactating cows and/or steers ${ }^{2,10,11)}$. When an animal fat (tallow) is fed as dietary supplement to increase energy supply to fattening ruminants, few investigations showed positive results ${ }^{11,13}$.

In the present study, a possibility of using treated animal fat an energy source in fattening ruminants, was investigated. Two experiments were carried out to examine the effect of supplemented tallow on feed digestion and on fat nutrition, when the diets fed to fattening sheep were added with treated (spray-dried) beef tallow (BT).

\section{Materials and Methods}

Two experiments were conducted in this study. Experiment 1 consisted of three types of BT supplements (1\%/DM); A) spray-dried BT coated with casein $(2.5 \%, \mathrm{w} / \mathrm{w})$ and whey powder $(17.5 \%, \mathrm{w} / \mathrm{w}), \mathrm{B})$ spray-dried BT coated with casein $(4.0 \%, \mathrm{w} / \mathrm{w})$, and C) spray-dried BT coated with sodium alginate $(5.0 \%, \mathrm{w} / \mathrm{w})$. In Experiment 2, using BT (A) which was thought to be the best in Expt. 1, the effect of BT supplementation ( 2 and $4 \% / \mathrm{DM}$ ) on feed utilization in sheep was determined.

\section{Animals and Management}

Four ruminally fistulated Japanese Corriedale sheep (two females and two wethers), weighing $49.2 \pm 3.8 \mathrm{~kg}$, were used in Expt. 1 . Three wethers (Japanese Corriedale $\times$ Suffolk), with an average initial body weight of $42.3 \pm 6.6$ $\mathrm{kg}$ were used in Expt. 2. All animals were kept in metabolism cages throughout the experimental period, and fed $2.2 \%$ dry matter (DM) diet (Table 1) per kilogram body weight per day. Fresh water and salt licks containing trace minerals were available at all times. One-half of the daily ration was given at 09:00 and the other half at $17: 00$.

\section{Treatments and Design}

Experiment 1. Four sheep were allotted to a $4 \times 4$ Latin square design to determine the usage of 3 BTs (A, B, and C) and control. Each BT was supplemented to the $1 \%$ level dietary DM.

Experiment 2. Threc wethers were also allotted to a $3 \times 3$ Latin square design to examine the effect of three levels of BT administration (i.e., 0,2 , and $4 \%$ dietary DM).

\section{Sample Collection}

In Experiments 1 and 2, a 5-day sampling period was preceded by a 7-day preliminary period, and faeces and urine were collected daily just before the morning feeding. On the final day of each trial, approximately $100 \mathrm{~m} l$ of ruminal contents were sampled through the ruminal cannula at $09: 00,10: 00,11: 00,12: 00$,

Table 1. Ingredient and chemical composition of basal diet

\begin{tabular}{lcc}
\hline \hline \multicolumn{1}{c}{ Ingredient, \% } & Expt. 1 & Expt. 2 \\
\hline Timothy hay (Phleum pratense L.) & 40.0 & - \\
Sudangrass hay (Sorghum sudanense (Piper) Stapf.) & - & 40.0 \\
Rolled barley & 49.5 & 49.5 \\
Wheat bran & 10.0 & 10.0 \\
Calcium carbonate & 0.5 & 0.5 \\
\hline Chemical composition, \% of DM & & \\
Organic matter & 94.8 & 90.6 \\
Crude protein & 8.2 & 9.6 \\
Crude fat & 2.8 & 2.7 \\
Crude fiber & 15.9 & 12.6 \\
NEE' & 67.9 & 65.7 \\
\hline
\end{tabular}

${ }^{1}$ Nitrogen free extract 


\section{FUJIHARA MAEDA MATSUI and NARUSE}

$14: 00$ and $16: 00$ to measure the $\mathrm{pH}$ and the concentrations of ammonia and volatile fatty acids (VFAs) in the rumen. Similarly, approximately $10 \mathrm{~m} l$ of jugular blood was collected at $09: 00,12: 00,14: 00$ and $16: 00$ to determine the concentrations of triglyceride (TG), glucose, free fatty acids (FFA) and cholesterol in blood plasma.

\section{Analytical Methods}

Feed and excreta : Nitrogen in the diet, feces and urine were analyzed by the Kjeldahl method, and the contents of crude fat, crude fiber and crude ash in the diet and feces were determined by AOAC method ${ }^{9)}$. Lipid content in the feed apart from the crude fat, was determined by the chloroform-methanol extraction method $^{133}$.

Ruminal contents: Ruminal $\mathrm{pH}$ value was measured by a glass-electrode method using a pH meter (Horiba M.8L, Horiba Seisakusho Co. Kyoto. Japan). Ammonia in the ruminal fluid was analyzed by the method of Oser et $a l^{9}{ }^{9)}$, and VFAs were determined by gas chromatography ${ }^{63}$.

Blood plasma:Packed cell volume was checked by the capillary method. TG and cholesterol in blood plasma were determined by the acetyl-acetone method ${ }^{7)}$ and cholesterol oxidase phenol method ${ }^{16)}$, respectively, using commercial test-reagents (Wako Chemical Co. Ltd. Osaka JAPAN). The concentrations of cholesterol in lipo-protein fractions were measured by the ultracentrifugation-method ${ }^{14)}$. Free-fatty acids were analyzed by the method of Duncombe ${ }^{4)}$ using commercial test-reagents (Wako Chemical). Blood glucose concentration was measured using the Unitest System (Model 300, Biodynamics, Inc., USA).

\section{Statistical Methods}

Statistical analysis consisted of an analysis of variance and a mean separation using Tukey's multiple range test ${ }^{18)}$.

\section{Results}

The sheep in both experiments ate almost completely daily amounts of mixed diet equivalent to approximately $2.2 \%$ of their body weight, so the orts were negligible. There was no clear effect of BT supplementation on appetite of animals, when it was added at $1-4 \%$ per

Table 2. Apparent digestibility, nitrogen balance and faecal excretion of alkali earth metal-salt (soap) (Expt. 1)

\begin{tabular}{|c|c|c|c|c|}
\hline Item & Control & $\mathrm{BT}^{\mathrm{I}}-\mathrm{A}$ & $\mathrm{BT}-\mathrm{B}$ & $\mathrm{BT}-\mathrm{C}$ \\
\hline \multicolumn{5}{|l|}{ Apparent digestibility, $\%$} \\
\hline Organic matter & $59.4 \pm 0.5^{2}$ & $58.8 \pm 0.6$ & $58.7 \pm 1.2$ & $59.0 \pm 0.7$ \\
\hline Crude protein & $56.6 \pm 1.7$ & $53.4 \pm 2.2$ & $52.7 \pm 2.1$ & $51.8 \pm 1.9$ \\
\hline Crude fat & $55.4 \pm 1.4^{\mathrm{a}}$ & $64.2 \pm 1.6^{\mathrm{b}}$ & $62.4 \pm 1.8^{\mathrm{b}}$ & $60.8 \pm 2.1^{\text {ab }}$ \\
\hline Crude fiber & 45. $1 \pm 7.4$ & $44.6 \pm 7.2$ & $44.7 \pm 5.7$ & $44.2 \pm 6.3$ \\
\hline $\mathrm{NEE}^{3}$ & $42.6 \pm 2.1$ & 42. $2 \pm 1.8$ & $41.6 \pm 1.9$ & $43.6 \pm 0.9$ \\
\hline Faecal alkali metal-salt (soap), g/d & $0.60 \pm 0.02$ & $0.64 \pm 0.02$ & $0.67 \pm 0.01$ & $0.68 \pm 0.02$ \\
\hline \multicolumn{5}{|l|}{ 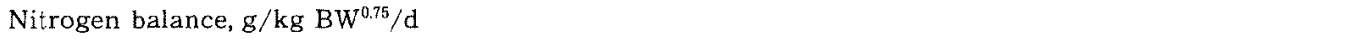 } \\
\hline Total intake & $0.71 \pm 0.03$ & $0.71 \pm 0.04$ & $0.71 \pm 0.02$ & $0.71 \pm 0.03$ \\
\hline Faecal & $0.24 \pm 0.01$ & $0.23 \pm 0.02$ & $0.24 \pm 0.01$ & $0.24 \pm 0.01$ \\
\hline Urinary & $0.23 \pm 0.02$ & $0.21 \pm 0.03$ & $0.19 \pm 0.04$ & $0.19 \pm 0.03$ \\
\hline Retention & $0.24 \pm 0.02$ & $0.26 \pm 0.02$ & $0.27 \pm 0.02$ & $0.27 \pm 0.02$ \\
\hline
\end{tabular}

\footnotetext{
${ }^{1}$ Beef tallow.

${ }^{2}$ Mean \pm S.D. of 4 sheep.

${ }^{3}$ Nitrogen free extract.

$a, b$ Values with different superscript letters differ $(\mathrm{p}<0.05)$.
} 
dietary DM.

Experiment 1. Apparent digestibilities of crude protein, crude fiber and nitrogen free extract (NFE) were almost the same in all the treated BT supplementation. Digestibility of crude fat (ether extract) was higher $(P<0.05)$ in all the treated BT supplementation than that in the control (Table 2). In the balance trial, ni-

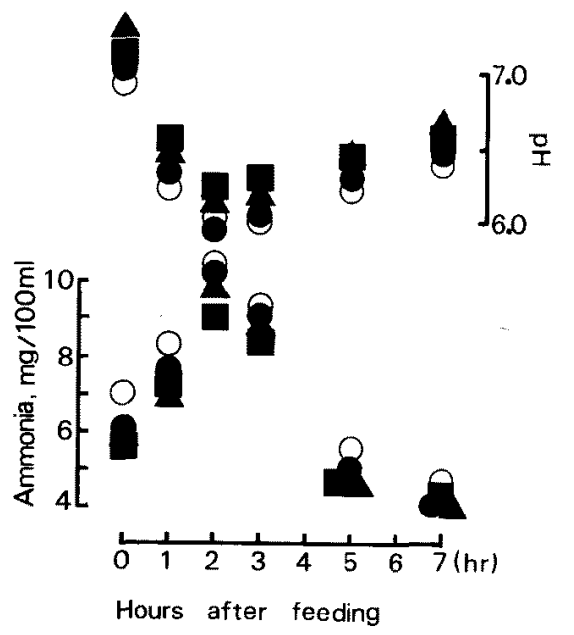

Fig. 1. The time course changes of $\mathrm{pH}$ and ammonia in the rumen fluid of sheep after morning feeding.

$\mathrm{O}=$ control, $\quad \mathbf{O}=\mathrm{BT}-\mathrm{A}, \quad \mathbf{\Delta}=\mathrm{BT}-\mathrm{B}, \quad \mathbf{\quad}=\mathrm{BT}-\mathrm{C}$. (Expt. 1) trogen retention was positive in all treatments, and there were no differences among the treatments. As shown in Fig. 1, ruminal pH values after morning feeding did not change with the change in dietary treatments. The time course changes in ruminal ammonia level after morning feeding tended to decrease slightly with BT supplementations. There was a decreasing tendency for the concentration of certain VFAs in ruminal fluid, such as acetic acid whereas that of propionic acid increased after BT supplementation, but not significantly (Table 3).

The haematocrit value was almost similar in all treatments (Table 4). The glucose concentration in plasma was higher $(\mathrm{P}<0.05)$ in $\mathrm{BT}$ supplemented groups than in control (Fig.2). As shown in Table 4, the concentration of TG in plasma was increased $(\mathrm{P}<0.05)$ with all $\mathrm{BT}-$ supplemented groupes compared with that in control, and the concentration of cholesterol in plasma was also higher $(\mathrm{P}<0.05)$ in the former than in the latter. The concentration of FFA, on the contrary, did not increase aftcr feeding the BT-supplemented feed (Table 4). The plasma FFA level after feeding BT-B was slightly higher compared with that after feeding other BTs or control diet. In the time course changes of FFA level in plasma, the

Table 3. The $\mathrm{pH}$ value and the concentrations of ammonia and VFAs in the rumen fluid of sheep (Expt. 1)

\begin{tabular}{lcccc}
\hline \multicolumn{1}{c}{ Item } & Control & BT $-\mathrm{A}$ & BT-B & BT-C \\
\hline $\mathrm{pH}$ value & $6.31 \pm 0.32^{2}$ & $6.36 \pm 0.34$ & $6.50 \pm 0.37$ & $6.51 \pm 0.32$ \\
Ammonia, $\mathrm{mg} / \mathrm{d} l$ & $7.62 \pm 2.13$ & $7.12 \pm 2.29$ & $6.75 \pm 2.07$ & $6.57 \pm 1.76$ \\
Acetic acid, $\mathrm{mM} / \mathrm{d} l$ & $4.02 \pm 0.60$ & $3.78 \pm 0.58$ & $3.80 \pm 0.73$ & $3.79 \pm 0.50$ \\
Propionic acid, mM/d $l$ & $0.89 \pm 0.18^{\mathrm{a}}$ & $1.06 \pm 0.27^{\text {bc }}$ & $1.20 \pm 0.3^{\mathrm{b}}$ & $0.99 \pm 0.18^{\mathrm{ac}}$ \\
Butyric acid, $\mathrm{mM} / \mathrm{d} l$ & $0.45 \pm 0.16$ & $0.38 \pm 0.17$ & $0.40 \pm 0.20$ & $0.37 \pm 0.16$ \\
Valeric acid, $\mathrm{mM} / \mathrm{d} l$ & $0.09 \pm 0.03$ & $0.06 \pm 0.05$ & $0.05 \pm 0.04$ & $0.07 \pm 0.03$ \\
Total VFAs, $\mathrm{mM} / \mathrm{d} l$ & $5.35 \pm 0.82$ & $5.28 \pm 0.92$ & $5.44 \pm 0.97$ & $5.22 \pm 0.79$ \\
A : P ratio & $4.51 \pm 0.52$ & $3.57 \pm 0.47$ & $3.17 \pm 0.61$ & $3.83 \pm 0.39$ \\
\hline
\end{tabular}

\footnotetext{
${ }^{1}$ Beef tallow.

${ }^{2}$ Mean \pm S.D. of 4 sheep.

${ }^{3}$ Acetic acid/Propionic acid.

a, b, c Values with different superscript letters differ $(p<0.05)$
} 
FUJIHARA MAEDA MATSUI and NARUSE

Table 4. Haematocrit value and the concentrations of glucose, triglyceride, total cholesterol, and free fatty acids in blood plasma of sheep (Expt. 1)

\begin{tabular}{lllll}
\hline \multicolumn{1}{c}{ Item } & Control & BT $-\mathrm{A}$ & BT-B & BT-C \\
\hline Haematocrit value & $25.8 \pm 0.3^{\text {a }}$ & $25.9 \pm 2.0$ & $24.9 \pm 2.7$ & $26.6 \pm 1.8$ \\
Glucose, mg/d $l$ & $45.3 \pm 5.6$ & $50.1 \pm 6.7$ & $51.5 \pm 6.6$ & $52.8 \pm 6.4$ \\
Triglyceride, $\mathrm{mg} / \mathrm{d} l$ & $74.8 \pm 3.8^{\mathrm{a}}$ & $95.0 \pm 1.6^{\mathrm{b}}$ & $93.5 \pm 1.2^{\mathrm{b}}$ & $91.3 \pm 2.2^{\mathrm{b}}$ \\
Total cholesterol, $\mathrm{mg} / \mathrm{d} l$ & $68.5 \pm 1.1^{\mathrm{a}}$ & $75.8 \pm 1.1^{\mathrm{b}}$ & $76.0 \pm 0.7^{\mathrm{b}}$ & $76.8 \pm 0.8^{\mathrm{b}}$ \\
Free fatty acids, $\mathrm{mEq} / l$ & $0.25 \pm 0.04$ & $0.27 \pm 0.04$ & $0.30 \pm 0.05$ & $0.26 \pm 0.04$ \\
\hline
\end{tabular}

${ }^{1}$ Beef tallow.

${ }^{2}$ Mean \pm S.D. of 4 sheep.

a,b Values with different superscript letters differ $(\mathrm{p}<0.05)$.

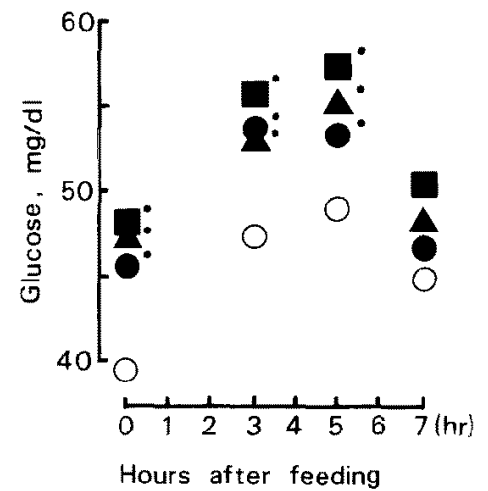

Fig. 2. The time course change in concentration of blood glucose in sheep after morning feeding.

$\mathrm{O}=$ control, $-\mathrm{BT}-\mathrm{A}, \mathbf{\Delta}=\mathrm{BT}-\mathrm{B}, \mathbf{D}=\mathrm{BT}-\mathrm{C}$.

* : Significantly different from control $(P<0.05)$. (Expt. 1)

FFA level tended to decrease after feeding the diets, which could be due to an increase in the supply of dietary energy by ingestion of feed (Figure 3).

Experiment 2. As shown in Table 5, apparent digestibilities of organic matter, crude protein and NFE were not affected by the supplementation of BT of any level. The digestibility of crude fiber tended to decrease with the supplementation of BT, and crude fat digestibility also decreased in both the 2 and 4 percent level with BT supplements. In the rumen fluid, the concentration of acetic acid tended to decrease with BT supplement, while

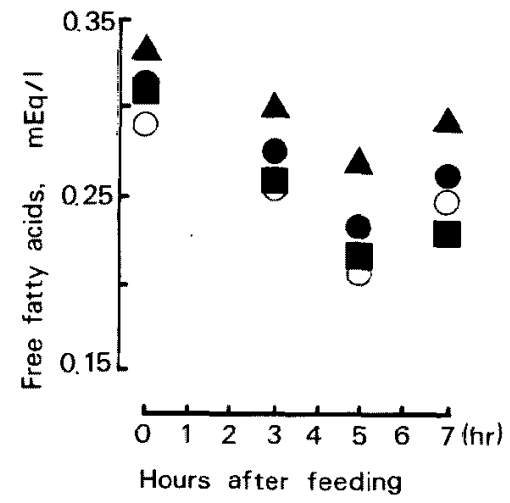

Fig. 3. The time course changes in concentration of free fatty acids in the plasma of sheep after morning feeding. $\mathrm{O}=$ control, $\quad \mathbf{O}=\mathrm{BT}-\mathrm{A}, \quad \mathbf{\Delta}=\mathrm{BT}-\mathrm{B}, \quad \mathbf{\quad}=\mathrm{BT}-\mathrm{C}$.
(Expt. 1)

propionic acid level tended to increase (Table 5). The ratio of acetic acid to propionic acid (A: $\mathrm{P}$ ratio) was also lowered $(\mathrm{P}<0.05)$ with supplementation of BT in the diet. The concentration of total VFAs in the rumen fluid tended to decrease with BT supplement. The concentration of TG in plasma was increased (P $<0.05$ ) after feeding the diet with BT supplement as compared with that after feeding control diet (Table 6). The total cholesterol in plasma was higher $(P<0.05)$ after feeding the diet with BT supplements, and was enhanced with the increase of dietary level of BT supplementation (Table 6). The concentration of cholesterol in plasma in low density 
Utilization of Beef-Tallow in Sheep

Table 5. Apparent digestibility and the concentrations of VFAs in rumen fluid of sheep (Expt. 2)

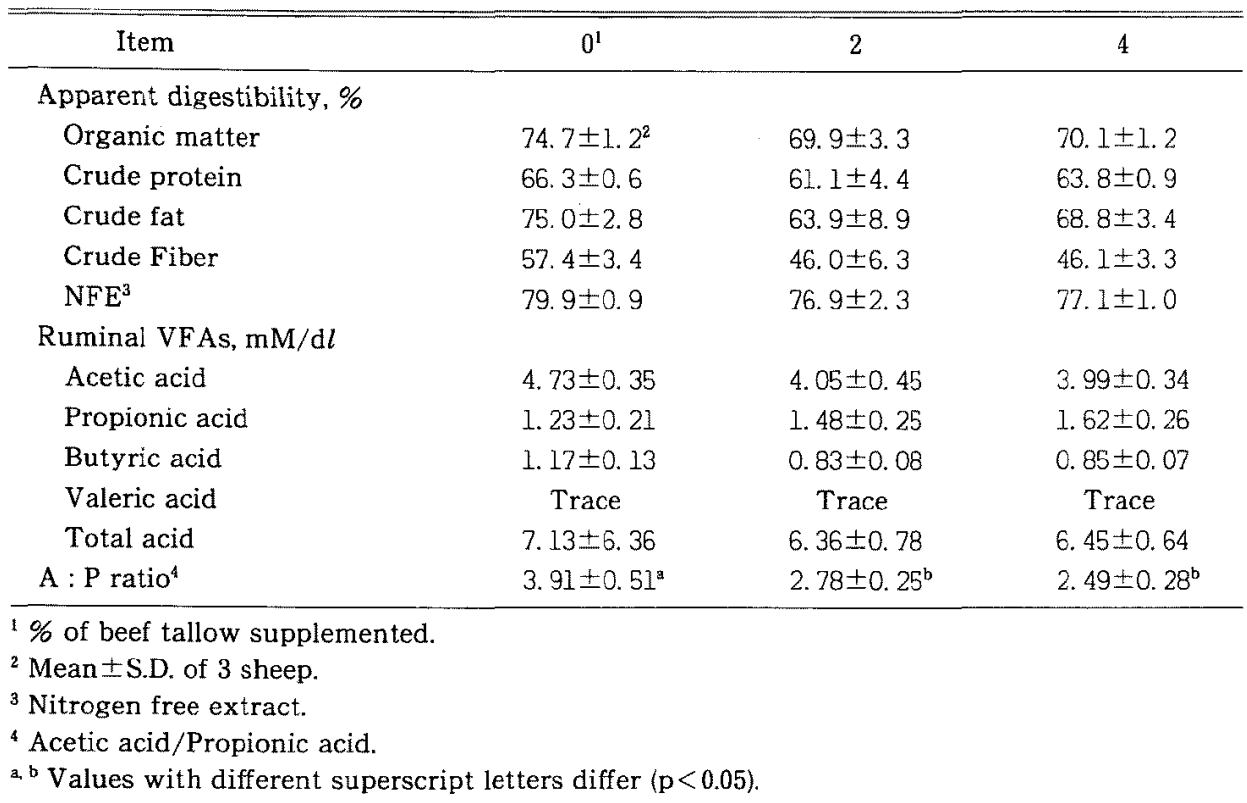

Table 6. The concentrations of triglyceride, cholesterol, and free fatty acids in blood plasma of sheep (Expt. 2)

\begin{tabular}{ccccc}
\hline Item & & $0^{1}$ & \multicolumn{1}{c}{2} & 4 \\
\hline Triglyceride, $\mathrm{mg} / \mathrm{d} l$ & $0^{2}$ & $99.5 \pm 14.2^{\mathrm{d}}$ & $144.5 \pm 25.6$ & $161.8 \pm 7.1$ \\
& 5 & $100.1 \pm 23.2$ & $133.3 \pm 18.4$ & $175.4 \pm 16.7$ \\
& & $98.4 \pm 10.3^{5 \mathrm{a}}$ & $137.1 \pm 13.2^{\mathrm{b}}$ & $155.7 \pm 10.7^{\mathrm{b}}$ \\
Choresterol, $\mathrm{mg} / \mathrm{d} l$ & 0 & $68.9 \pm 7.5$ & $95.3 \pm 4.3$ & $105.5 \pm 6.9$ \\
& 5 & $71.6 \pm 7.0$ & $81.9 \pm 8.6$ & $104.6 \pm 3.8$ \\
$\mathrm{FFA}^{3}, \mathrm{mEq} / l$ & & $70.2 \pm 7.2^{5 \mathrm{a}}$ & $88.7 \pm 5.1^{\mathrm{b}}$ & $105.0 \pm 5.3^{\mathrm{b}}$ \\
& 0 & $0.25 \pm 0.03^{*}$ & $0.27 \pm 0.04^{*}$ & $0.32 \pm 0.05^{*}$ \\
& 5 & $0.19 \pm 0.01^{* *}$ & $0.20 \pm 0.01^{* *}$ & $0.21 \pm 0.02^{* *}$ \\
\hline
\end{tabular}

$1 \%$ of beef tallow supplemented.

${ }^{2}$ Hours after morning feed.

${ }^{3}$ Free fatty acid.

${ }^{4}$ Mean \pm S.D. of 3 sheep.

${ }^{5}$ Mean \pm S.D. of 12 samples (4 samples $\times 3$ sheep).

a, b Values with different superscript letters differ $(\mathrm{p}<0.05)$.

*** Values with different superscript symbols differ $(p<0.05)$.

lipoprotein (LDL) tended to increase after feeding the diet with $4 \% \mathrm{BT}$ supplement, and the figure after feeding 4\% BT diet was higher $(\mathrm{P}<$ 0.05) than that of control (Table 7). The con- centrations of cholesterol in other lipo-protein fractions (VLDL and HDL) also tended to increase with the BT supplementation diets. As shown in Table 6, the concentration of FFA in 
FUJIHARA MAEDA MATSUI and NARUSE

Table 7. The concentration of cholesterol in lipoprotein fractions of sheep (mg/dl) (Expt. 2)

\begin{tabular}{lccc}
\hline \multicolumn{1}{c}{ Item } & $0^{1}$ & 2 & 4 \\
\hline VLDL $^{2}$ (Chylomicron) & $4.05 \pm 1.46^{*}$ & $6.14 \pm 0.18$ & $6.55 \pm 0.65$ \\
LDL $^{3}$ & $26.68 \pm 3.02^{\mathrm{a}}$ & $32.38 \pm 4.08^{\mathrm{ab}}$ & $38.93 \pm 2.88^{\mathrm{b}}$ \\
VHDL $^{4}$ & $4.14 \pm 1.61$ & $2.75 \pm 0.90$ & $4.37 \pm 1.08$ \\
HDL $^{5}$ & $35.31 \pm 4.34$ & $47.39 \pm 5.89$ & $55.22 \pm 7.30$ \\
\hline
\end{tabular}

$1 \%$ of BT supplemented.

${ }^{2}$ Very low density lipoprotein.

${ }^{3}$ Low density lipoprotein.

${ }^{4}$ Very high density lipoprotein.

${ }^{5}$ High density lipoprotein.

${ }^{*}$ Mean \pm S.E. of 3 sheep.

a. $b$ Values with different superscript letters differ $(\mathbf{p}<0.05)$

blood plasma was not changed with BT supplementation, although there was a clear $(\mathrm{P}$ $<0.05)$ reduction in plasma $F F A$ level at 5 hours after morning feeding in all the diet.

\section{Discussion}

Digestion and $N$ balance. When BT supplement was relatively high in the diet $(2-4 \%)$ $\mathrm{DM})$, the digestibility of crude fiber decreased (about 10\%), but not significantly $(\mathrm{P}>0.05)$ because there were quite big variances among individuals (Expt. 2). Similar result had been reported by other workers that ruminal digestibility of fiber was reduced by tallow fatty acids $(9 \%)$ in steers, but not significantly ${ }^{12}$. These findings showed that treated BT added in the present study was not degraded in the rumen, but by-passed the rumen and digested in the lower gut. It was concluded that BT (A) was useful as a supplement of dietary fat with little effect on digestion in the rumen.

It is generally known that an ordinary crude fat (ether extract) contained some pigments of wax in feed which were hardly absorbed in the gut. As indicated in Table 2, the amount of alkali earth metal-salt (soap) formed from longchain fatty acids in the faeces, calculated by subtracting chloroform-methanol-HCL-extracted fat from chloroform-methanol-extracted fat, was very small. It was reported that when fat in a diet is degraded in the rumen, the same some soaps described above were formed from long chain fatty acids and calcium salts in the rumen ${ }^{12)}$. These soaps were difficult to digest, so they could increase after degradation of large amount of fat in the rumen. Faecal soap did not increase in the treated group. These findings suggested that BT supplemented in this experiment could have mostly by-passed degradation in the rumen as a form of $\mathrm{TG}$ through the lower gut, and then absorbed com. pletely in the intestines.

With utilization of dietary nitrogen, there were no clear effects of supplementation of BT on the nitrogen retention, and similar results are found in other report $t^{3}$.

Ruminal Fermentation. In this experiment, $\mathrm{pH}$ value and ammonia concentration in rumen fluid did not change after feeding the diet with BT. This indicated that BT supplementation did not have an obvious effect on the microbial fermentation activity in the rumen, particularly on the digestion of dietary nitrogen. As shown in Tables 3 and 5 , the ruminal level of acetic acid tended to decrease slightly, while that of propionic acid tended to increase after feeding the diet with BT. This result agreed with that reported by other workers using dairy cows fed the diet with fat ${ }^{5)}$. In general, acetic acid was thought to be produced mainly from the fermentation of fibrous material, such as cellulose, and propionic acid from non- 
structual carbohydrates, such as starch in the rumen. Our result showed there was little reduction in ruminal level of acetic acid, even without reduction of crude-fiber digestion, and an increase in ruminal level of propionic acid in the feeding of BT supplemented diet (Expt 1.). This indicated that glycerol produced by BT degradation in the rumen was used to produce propionic acid, and that the long-chain fatty acids produced at the same time had little effect on the control of the ruminal digestion of dietary fiber, although there was not any remarkable reduction in the digestibility of dietary fiber. However, when the dietary BT level was increased (Expt. 2.), the extent of decrease in acetic acid level of rumen fluid was quite high, and the $\mathrm{A} / \mathrm{P}$ ratio was lowered $(\mathrm{P}<$ 0.05 ). This would be mainly due to a reduction of fiber digestion after feeding the diet with 2$4 \%$ BT.

The Concentrations of Some Metabolites in Plasma. In ruminants, it was found that propionic acid produced in the rumen was a main precursor of glucose $\mathrm{e}^{12)}$, and glycerol was also positively used for gluconeogenesis in the liver when fat feeding was increased, or when animals were fasted so the catabolization of body fat could be accelerated as an energy source (fatty acids) resulting in an increase of released glycerol in the blood stream. In this study, the concentration of glucose in plasma increased $(\mathrm{P}<0.05)$ after feeding diet with $\mathrm{BT}$ supplement, which could be due to an increase of propionic acid absorption, and also an increase of released glycerol in the metabolism of dietary TG. Furthermore, fatty acids produced after absorption of BT could be used as a source of energy, so the increased amounts of fatty acids absorbed partially might have saved the use of glucose as energy source. Consequently, this sparing action of fatty acids might contribute to an increase of glucose in plasma after feeding BT-supplemented diets.

The fat in the BT used in this study was thought to compose mainly TG that was absorbed easily in the small intestine (Table 2), therefore, a significant increase in the level of TG in plasma after feeding the diet with BT could reflect an increased TG absorption through the digestive tract. The increase of TG in plasma might be thought to contribute fat deposition during fattening of animals.

The cholesterol in plasma significantly increased after feeding the diet with BT (Expt. 1.). This could be due to an increase in concentration of TG in plasma, because TG is closely related to cholesterol synthesis in the liver. It is well known that cholesterol level in plasma is raised at the latter term during the fattening period when fat is deposited in the muscles in fattening beef cattle ${ }^{* 4)}$. Plasma cholesterol acts as a carrier which transports esterified fatty acids (cholesterol ester) in the blood. The increment of plasma cholesterol level in the present study could, therefore, indicate that the transport of fatty acids from the liver to the peripheral tissues was very active.

From the results obtained in the present experiment, it was suggested that treated (spraydried) BT could efficiently provide energy to animals without reducing fiber digestion of feed. Furthermore, BT supplementation induced elevation of TG and cholesterol concentrations in plasma suggest an increment of fat deposition in the body.

\section{Acknowledgement}

The authors gratefully acknowledge the kind assistance of Mr. W. UEDA during the course of experiment.

\section{References}

1) Brethour JR, Sirny RJ, Tillman AD. Further studies concerning the effects of fats in sheep rations. J. Anim. Sci., 17 : 171-179. 1958.

2) Chalupa W, Vecchiarelli B, Elser AE, Kronfeld DS, Sklan D, Palmquist DL. Ruminal fermentation in vivo as influenced by long-chain fatty acids. J. Dairy Sci., 69 : 1293-1301. 1986.

\footnotetext{
*) Hidaka S, Hidari H. Jpn. Soc. Anim. Nutr. Met., 35 : 133-154. 1991. (in Japanese).
} 


\section{FUJIHARA MAEDA MATSUI and NARUSE}

3) Davison KL, Woods W. Effect of calcium and magnesium upon digestibility of a ration containing corn oil by lambs. J. Anim. Sci., 22 : 2729. 1963.

4) Duncombe WG. The colorimetric micro-determination of nonesterified fattyacids in plasma. Clin. Chim. Acta., 9 : 122-125. 1964.

5) Eastridge ML, Firkins JL. Feeding hydrogenated fatty acid and triglycerides to lactating dairy cows. J. Dairy Sci., $74: 2610^{-}$ 2616. 1991.

6) Erwin ES, Marco GJ, Emery EM. Volatile fatty acid analyses of blood and rumen fluid by gas chromatography. J. Dairy Sci., 44 : 1768-1774. 1961.

7) Fletcher MJ. A colorimetric method for estimating serum triglycerides. Clin. Chim. Acta., $22: 393-397.1968$.

8) Grainger RB, Bell MC, Stroud JW, Baker FH. Effect of various cations and corn oil on crude cellulose digestibility by sheep. J. Anim. Sci., $20: 319-322.1961$.

9) Hoitz $\mathrm{H}$ (ed.). Official Method of Analysis. 9 th ed. 283-288. A.O.A.C. Washington D.C. 1960.

10) Jenkins TC, Palmquist DL. Effect of fatty acids or calcium soaps on rumen and total nutrient digestibility of dairy rations. J. Dairy Sci., 67 : 978-986. 1984.

11) Kronfeld DS, Donoghue S, Naylor JM, Johnson $\mathrm{K}$, Bardley CA. Metabolic effects of feeding protected tallow to dairy cows. J. Dairy Sci.,
$63: 545-552.1980$.

12) Lindsay DB. Cabohydrate metabolism in ruminants. In : AT. Phillipson (ed.) Physiology of digestion and metabolism in the ruminant. 438-451. Oriel Press Ltd., Newcastle upon Tyne, England, UK, 1970.

13) Marchello JA, Dryden FD, Hale WH. Bovine serum lipids. I. The influence of added animal fat to the ration. J. Anim. Sci., 32 : 1008-1015. 1971.

14) Okada M, Hara I. Analysis of lipo-protein. In : Nihon-Seikagakukai (ed.) Zoku-Seikagaku Jikken-Kouza (No.3). 597-612. Tokyo Kagaku Doujin Ltd. Tokyo, Japan. 1986. (in Japanese).

15) Oser BL. Hawk's Physiological Chemistry, 14 th ed. 1219-1221. McGraw Hill Co. New York. 1965.

16) Richmond W. Preparation and properties of a cholesterol oxidase from Nocardia sp. and its application to the enzymatic assay of total cholesterol in serum. Clin. Chem., $19: 1350$ 1356. 1973.

17) Ward JK, Tefft CW, Sirny RJ, Edwards HN, Tillman AD. Further studies concerning the effect of alfalfa ash upon the utilization of low-quality roughages by ruminant animals. J. Anim. Sci., 16 : 633 641. 1957.

18) Yoshida M. Design of Experimental for Animal Husbandry. 68-86. Yokendo Co. Tokyo, Japan. 1975. (in Japanese). 
粉末牛脂添加がヒッジにおける飼料の消化，第一胃内発酵 および脂肪栄養に及ぼす影響

\author{
藤原 勉・前田 諭・松井 徹・成瀬治巳
}

島根大学生物資源科学部, 松江市 690

\begin{abstract}
加工処理した牛脂（粉末牛脂）をヒツジの肥育用飼料に添加した場合の飼料の利用性および脂質代謝 に及ぼす影響について調查し，更に肥育時の肉質改善効果の可能性について検討した．眮料の乾物当り $1 \%$ の牛脂を添加した場合では，有機物および各栄養素の見かけの消化率への影響はみられなかったが， 添加量が增加（乾物当り 2 4\%）する之，粗瀻維の消化率が低下する傾向がみられた，第一胃内汁液中 の総 VFA 濃度では牛脂添加による明らかな影響はみられなかったが，プロピオン酸㐮度は牛脂添加に

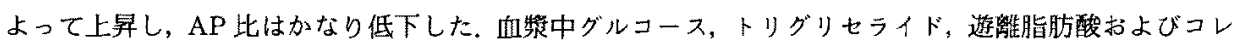
ステロール濃度は牛脂添加によって有意に增加した，以上の結果から，本実験で用いた粉末牛脂は，上

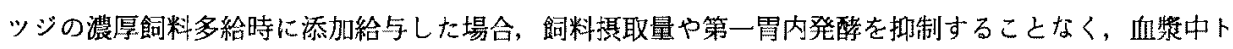
リグリセライドの上异等の脂質栄養を改善することにより，末梢組織への脂肪沋着を増加させる可能性 のあることが示された.
\end{abstract}

日畜会報， 67 (1)：14-23, 1996 